\title{
Government Domestic Borrowing and Private Sector Credit Crowding out: Empirical Evidence from Nigeria
}

\author{
Abiodun Akanbi \\ Department of Business Administration, Nile University of Nigeria, Abuja, Nigeria \\ Email address: \\ abiodunakanbi1@yahoo.com \\ To cite this article: \\ Abiodun Akanbi. Government Domestic Borrowing and Private Sector Credit Crowding out: Empirical Evidence from Nigeria. Journal of \\ Investment and Management. Vol. 9, No. 4, 2020, pp. 100-106. doi: 10.11648/j.jim.20200904.12
}

Received: July 13, 2020; Accepted: August 21, 2020; Published: December 31, 2020

\begin{abstract}
The impact of government domestic borrowing on the private sector credit has been a subject of great interest to researchers in finance. This study looked at the impact of government domestic borrowing on private sector credit in Nigeria. Government domestic borrowing can affect the private sector by crowding out private sector credit directly or indirectly through rising interest rates. The study employed an ex-post research methodology. Secondary data was collected from the Debt Management Office Nigeria and the Central Bank of Nigeria. The study covered a 10-year period from 2009 to 2018 . An OLS multiple regression model was used. Government domestic borrowing was proxied by federal government bond issuances as the dependent variable. The deposit money banks' prime lending rates, private sector lending by the banks, the bank's investment in treasury bills and government bonds were the independent variables. The data was tested for heteroscedasticity, stationarity, normality, multicollinearity and serial correlation to examine the robustness of the model. The results showed that prime lending rate has a positive effect on government bond issuance although not significant. The findings also indicated that there is a negative relationship between government domestic bond issuance and the banks credit to private sector. However, this relationship is not statistically significant implying that government borrowing may not have crowded-out private sector. The relationship between government bond issuances and bank investment in treasury bills and government bond is negative although not significant. The findings of this study suggest that government domestic borrowing in Nigeria may have resulted in the reduction of private credit and this works through the credit channel and the interest rate channel.
\end{abstract}

Keywords: Domestic Borrowing, Crowding out, Private Sector Credit, Interest Rate, Government Securities

\section{Introduction}

Nigeria has been offering double digit interest rate in its government securities in the last ten years. The high doubledigit returns could encourage banks to invest in government securities as opposed to actual financial intermediation of funds to the private sector. When governments borrow domestically, they tend to use up domestic private savings that would have been accessible for private sector lending [1]. This can reduce loanable funds and also raise the cost of capital for private borrowers. Domestic borrowing by the governments is common in both developed and developing economies [33]. In many markets domestic borrowing by governments can lead to crowding out of the private sector. The impact of government borrowing on private sector credit has been a topical issue in economics and finance $[16,32]$. The debate whether public and private sector borrowings are complements or substitutes is an unsettled empirical question in the field of development policy [31]. Government borrowing usually emanate from expansionary fiscal policy in order to meet the demand of the citizens in a bid to increase social services and provide infrastructure. Banks as financial institutions play very important roles in the economic development and growth of any country [15]. They channel scarce resources from the surplus economic units to the deficit economic units in an economy. They provide loan to deficit units in the form of short-term, medium term and long-term credit. Bank credits to a reasonable extend exert reasonable influence on the pattern and trend of economic growth in Nigeria [15].

Fiscal deficit financing has an impact on macroeconomic variables such as inflation, exchange rates, unemployment, interest rates and money supply [24]. The process of financing the needs of government give rise to public debts. The Nigerian government finance deficits through the sale of government 
securities in both the domestic market and international markets. The Debt Management Office (DMO) is the government agency established to centrally coordinate the management of Nigeria's debt. As at September 2019 Nigeria's domestic debt was $13,901,546,027,378.00$ naira. The domestic debts accounts for about $68 \%$ of the total public debt. This comprises of Federal Government Bond 10,074,909,394,592.00 (72.4\%) Federal Government Treasury bills,651,514,042,000.00 (19\%) other types of domestic debt instruments are the Green Bond, Treasury Bonds, Promissory Notes, Sukuk and the Savings Bond. The DMO conducts monthly auction of Federal Government Bond, bimonthly auction of treasury bills and quarterly auction for savings bonds. Other issuances do not follow a specific auction calendar [11].

The level of domestic credit measures financial resources provided to the private sector by banks and other financial institutions. Credit is the oil that greases the private sector. The more credit to the private sector reflects more opportunity for the private sector to grow and develop [8]. The degree of crowding-out depends on the nature of the response of the banks to a higher government borrowing and how they alter their balance sheets [19]. Access to safe government assets could allow the banks to take less risk by increase their lending to the government and borrowers could face higher borrowing costs. However, if banks have excess liquidity, a higher degree of lending to the government may not result in any significant reduction of credit to the private sector. The relationship between government borrowing and private credit is usually thought of as negative. If the government borrows one naira more from the banks, the banks are left with one naira less for the private sector lending. Fiscal policy effectiveness varies greatly depending on the extent of its crowding-out and crowding-in effects on the private sector [17]. Many empirical studies have shown that government borrowing crowds out the private sector [10]. Economic theories suggest that a reasonable level of debt should help both developing and developed countries enhance their economic growth [19]. Therefore, it is clear that these theoretical and empirical discussions had produced different and often conflicting results particularly the extent of the impact of government borrowing behaviour on private sector. The impact of government domestic borrowings can be through different channels. Government domestic borrowing can affect private sector by crowding out private sector credit directly (real crowding out), or indirectly through rising interest rates (financial crowding out). The magnitude of these potential consequences depends on the degree to which government domestic borrowing raises interest rates and or reduces private credit [8].

The objective of this study was to examine the relationship between government domestic borrowing and credit to the private sector in Nigeria. Most of the earlier studies were focused on the developed economies. This study was motivated by the fact that are dearth studies that has empirically investigated the relationship between government borrowing and private sector credit in Nigeria. Also, it is important to confront these theories with practical reality using recent data from Nigeria. This study also attempts to contribute to the literature on how government domestic borrowing behaviour impacts on private sector.

\section{Literature Review}

\subsection{Conceptual Review}

\subsubsection{Crowding out Effect}

Crowding out is described as partial loss of private capital formation. This is due to increase in borrowing government through sale of government securities [16]. This happens when government through its borrowing competes with the private sector for funds.

\subsubsection{Private Sector Credit}

This is level of domestic financial resources provided to the private sector by banks and other financial institutions. Bank's credit to private sector in Nigeria and other countries is said to be as the credit extended to the private sector only: both firms and households. This can be in form of loans, trade credits and other accounts receivable, that establish a claim for repayment.

\subsubsection{Government Domestic Borrowing}

Government borrowing is as result as a shortage of revenue over expenditure [13]. Government can finance its fiscal deficits through borrowing from domestic and external sources. Domestic borrowing means borrowing in local currency.

\subsection{Theoretical Review}

\subsubsection{Keynesian Crowding out and Crowding in Theory}

Public debt has generate debate and disagreements among economists, academia and policy makers in the history of modern government [18]. The Keynesian school believes that government spending is important to stimulate aggregate demand in the economy and in the process promote private sector investment. The Keynesian theory believes that fiscal policy expansion through increased government borrowing has insignificant impact in increasing the level of interest rate in the economy but rather, it has capacity to increase the level of productivity.

\subsubsection{Classical Crowding out Theory}

The classicalists are of the opinion that if government participates in actively in the economy through expansionary fiscal policy would lead to higher interest rates, reduced after-tax income and increased wages all of which reduce firms' profitability and by implication business investment. The consequence of this is that businesses will not expand They believe that despite the fact that government intervention has an impact on output, such impact is only temporary and in the longrun, its negative side effect of crowding out private investment does more harm than good to the economy, therefore, rendering fiscal policy ineffective and self-defeating [29].

\subsubsection{The Fiscal Allusion Theory}

This theory (see [6]) argued that because populace (voters) do not understand the inter-temporal budget constraint of the 
government, when offered a deficit financed expenditure programme. They tend to overestimate the benefit of current expenditures and underestimate future tax burden. As such, opportunistic politicians who want to be reelected take advantage of this confusion by spending more than they collect as taxes in order to please fiscally alluded voters [6]

\subsection{Empirical Review}

\subsubsection{Evidence from Nigeria}

Using a Structural Vector Autoregressions (SVAR),(see [2]) model to analyse the dynamics of government borrowing behaviour on the growth of private sector in Nigeria provided evidence that government borrowing behaviour has the propensity of impacting negatively on the effectiveness of private sector grow in Nigeria. In a study (see [27]) it was concluded that high interest rate crowds-out (reduces) private sector small and medium scale investment. Also, [3] found out that public sectors crowds out private investment in Nigeria. Similarly, [26] established that fiscal deficit has a significant negative effect on domestic credit in Nigeria. In their study (see [4]) concluded that governments fiscal dominance have a negative impact Deposit Money Banks' (DMBs) private sector credit allocation in Nigeria. While [9] using Maastricht treaty indicator and co-integration posits there is a negative long-run relationship between domestic debt and aggregate output and credit to private sector in Nigeria. Also [5] using Johnasen Co-integration test and Vector Error Correction Model in their study Public Debt and Private Investment in Nigeria analysis data from 1980-2010 concluded that domestic debt crowds out domestic investment in both short run and long run. Also [25] concluded that, domestic borrowing component of public borrowing crowds out private investment in Nigeria in a study Public Borrowing and Private Investment in Nigeria: Any crowding out effect? While [28] using data from 1988 to 2018 and adopting regression technique concluded that domestic debt has a significant positive impact on private sector credit.

\subsubsection{Evidence from Other Countries}

In Kenya [21] using data from 1975 to 2014 empirical confirmed that excessive domestic borrowing by the government negatively affect investment by the private sector. Using panel data from 60 developing countries [12] provided evidence that there is a significant crowding out effect of government borrowing on private credit in these countries. While [22] assessed the impact of government borrowing on the private sector credit in Zimbabwe using monthly data from 2012 to 2018 using a multivariate regression model and an unrestricted Vector Auto-regression (VAR) confirms a negative but not significant relationship between credit to government and credit to private sector, implying that credit to government may not have crowdedout private credit. In Malaysia in a study by [20]) Bond Market Development in Malaysia: Possible Crowding-Out from Persistent Fiscal Deficits: finds no evidence of crowding-out effects on Malaysia's domestic corporate bond market from the country's growing government debt market. In India,[16] finds evidence that fiscal deficit leads the interest rate rise of the corporate bond market, thereby empirically validating the possibility of financial crowding out in the Indian bond market.

In a study Government Domestic Debt, Private Sector Credit, and Crowding Out Effect in Oil-Dependent Countries [8] examined the crowding out effect of government domestic borrowing using a panel data for 28 oil-dependent countries over the period $1990-2012$. They found out that a $1 \%$ increase in government borrowing from domestic banks significantly decreases private sector credit by $0.22 \%$ and has no significant impact on the lending rate banks charge to the private sector. This finding suggests that government domestic borrowing has resulted in the shrinking of private credit and works through the credit channel and not through interest rate channel. Similarly [33] in Pakistan found out that $1 \%$ growth in governent borrowing leads to $0.08 \%$ of crowiding out of private sector credit which indicates a negative but small impact of government borrowing.

In China, between 2006 and 2013, local public debt crowded out the investment of private firms [17]. In Egypt [32] stated that Egypt has been relying heavily on debtfinancing from the banking sector to finance its growing deficit. They employed VAR model using quarterly data from 1970-2009 confirmed that banks shift their portfolio away from the private sector deemed risky loans to government debt-instrument. In Jordan [7] provided evidence that government borrowing from the domestic banks leads to crowding out of private credit.

\section{Research Methodology}

In this section the methodology of the empirical model used to achieve the objectives of this study is discussed.

\subsection{Sources of Data}

The study employed and ex-post research methodology design. Secondary data was collected from the Debt Management office and the Central Bank of Nigeria. The research covers a 10-year period of 2009 to 2018

\subsection{Model Specification}

$$
\mathrm{BDI}=\beta 0+\beta 1 \mathrm{CPS}+\beta 2 \mathrm{TBR}+\beta 3 \mathrm{FGB}+\beta 4 \mathrm{PNT}+\mu
$$

Where: $\mathrm{BDI}=$ Federal Government of Nigeria Bond Issued

$\mathrm{CPS}=$ Credit to Private Sector

$\mathrm{TBR}=$ Treasury Bills Investments made by Banks

$\mathrm{FGB}=$ Government Bond Investments made by Banks

$\mathrm{PNT}=$ Prime lending rate

$\beta 0$ is the intercept,

$\beta 1, \beta 2, \beta 3$, and $\beta 4$ are the slope (coefficients) of the explanatory variables.

$\mu$ is the stochastic or error term assumed to capture the influence of other exogenous factors that are capable of influencing dependent variable in the model. 


\section{Data Presentation, Analysis and Discussion of the Results}

\subsection{Introduction}

This section focused on, analysis and discussion of the results. The analysis was carried out using Ordinary Least Square (OLS) multiple regression method. Diagnostics test such as residual normality test, autocorrelation test and heteroskedasticity test was also conducted.

\subsection{Analysis of the Result}

\subsubsection{Descriptive Statistics}

Table 1. Descriptive Statistics.

\begin{tabular}{llllll}
\hline & BI & CP & PLR & SB & TB \\
\hline Mean & 1071173. & 12626.93 & 16.90000 & 1629.131 & 1877.961 \\
Median & 1021692. & 12429.12 & 16.85500 & 1644.750 & 2241.175 \\
Maximum & 1550464. & 16683.89 & 19.55000 & 2043.800 & 3065.790 \\
Minimum & 726500.0 & 9198.170 & 15.68000 & 1153.540 & 585.4500 \\
Std. Dev. & 238756.5 & 2931.426 & 1.103802 & 298.9246 & 902.6804 \\
Skewness & 0.639652 & 0.220128 & 1.308880 & -0.234420 & -0.363533 \\
Kurtosis & 2.789202 & 1.491867 & 4.472945 & 1.905785 & 1.606027 \\
Jarque-Bera & 0.700439 & 1.028455 & 3.759263 & 0.590465 & 1.029911 \\
Probability & 0.704534 & 0.597962 & 0.152646 & 0.744358 & 0.597527 \\
Sum & 10711731 & 126269.3 & 169.0000 & 16291.31 & 18779.61 \\
Sum Sq. Dev. & $5.13 \mathrm{E}+11$ & 77339351 & 10.96540 & 804203.3 & 7333488. \\
Observations & 10 & 10 & 10 & 10 & 10 \\
\hline
\end{tabular}

\subsubsection{Stationarity Result}

Table 2. Stationary Test.

\begin{tabular}{llll}
\hline Variable & I(0): (at Level) & I(1): (first difference) & I(2): (Second difference) \\
\hline BDI & Stationary $(0.0229)$ & & Stationary $(0.0250)$ \\
CPS & Non-Stationary $(0.8500)$ & Non-Stationary $(0.1118)$ & \\
PNT & Stationary $(0.0004)$ & & \\
FGB & Non-Stationary $(0.2887)$ & Stationary $(0.0456)$ & \\
TBR & Non-Stationary $(0.2458)$ & Stationary $(0.0109)$ & \\
\hline
\end{tabular}

Source: EViews 10 output.

From here we can observe that BDI and PNT are stationary at level (i.e they do revolve around the same mean), FGB and TBR are stationary at first difference and CPS is stationary at second difference. Augmented Dickey-Fuller test statistic from Table 2 also shows the stationarity levels. From Table 2 BDI and PNT at level are stationary with probability 0.0229 and 0.0004 respectively, FGB and TBR become stationary at first difference with probability 0.0456 and 0.0109 while CPS become stationary at second difference with probability 0.0250 . Therefore, the ordinary least square estimator will be run using the stationary level of the variables under study.

\subsubsection{Multiple Regression Result}

Table 3. Ordinary Least Square Estimator

\begin{tabular}{llll}
\hline Variable & Coefficient & Std. Error & t-Statistic \\
\hline C & 6.804232 & 7.968593 & 0.853881 \\
DDLNCPS & -0.333740 & 0.848069 & -0.393529 \\
DLNFGB & -0.175679 & 0.496056 & -0.354151 \\
DLNTBR & -0.092819 & 0.148427 & -0.625352 \\
LNPNT & 2.521902 & 2.827131 & 0.892036 \\
R-squared & 0.434457 & Mean dependent var & 0.7202 \\
Adjusted R-squared & -0.319601 & S.D. dependent var & 0.7467 \\
S.E. of regression & 0.220460 & Akaike info criterion & 0.4381 \\
Sum squared resid & 0.145807 & Schwarz criterion & 0.191915 \\
Log likelihood & 4.668130 & Hannan-Quinn criter. & 0.082968 \\
F-statistic & 0.576159 & Durbin-Watson stat & 0.132618 \\
Prob (F-statistic) & 0.702467 & & -0.251908 \\
\hline
\end{tabular}

Source: EViews 10 Output. 
The result on Table 3 shows that the coefficient of determination, $\mathrm{R}$ - Squared $\left(\mathrm{R}^{2}\right)=0.434457$ (43.5\%), which means that $43.5 \%$ of the variation in the dependent variable (BDI) can be accounted for by the independent variables; CPS, FGB, TBR and PNT. The result on Table 3 shows PNT have positive effect on BDI while CPS, FGB and TBR have negative effect on BDI though they are all not significant with probabilities greater than 0.05 at $95 \%$ confidence interval. The probability of the F-statistic (0.702467), shows

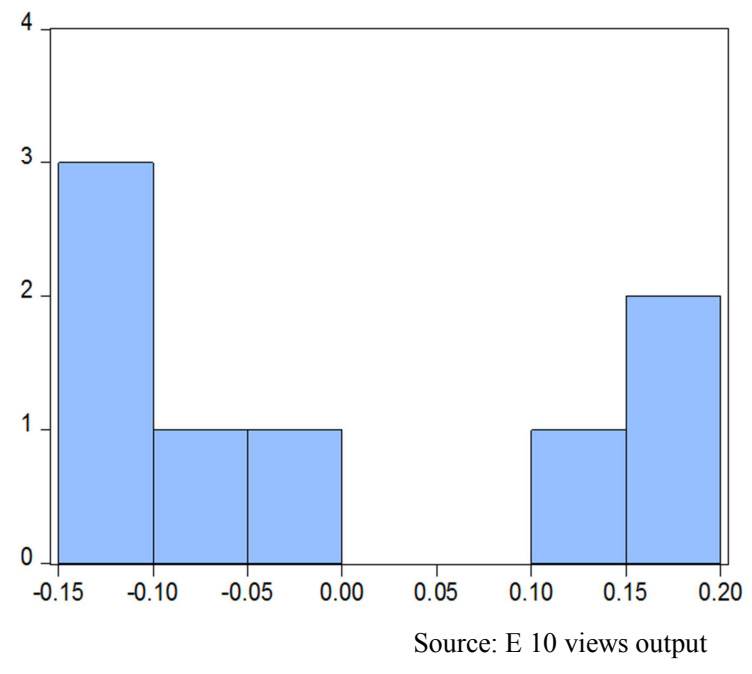

Figure 1. Residual Normality. that the independent variable combined have no significant effect on the dependent variable (BDI). The Durbin Watson statistic (1.9332) shows that the errors are not suffering from auto-correlation.

\subsubsection{Test for Residual Normality}

The figure 1 shows that the residuals are normally distributed with probability 0.589803 which is greater than 0.05

\subsubsection{Test for Heteroskedasicity}

Series: Residuals

Sample 310

Observations 8

Mean $\quad 1.11 \mathrm{e}-15$

Median $\quad-0.051399$

Maximum $\quad 0.192176$

Minimum $\quad-0.144556$

Std. Dev. $\quad 0.144325$

Skewness $\quad 0.345147$

Kurtosis $\quad 1.359485$

Jarque-Bera 1.055932

Probability $\quad 0.589803$

Table 4. Test for Heteroskedasicity.

\begin{tabular}{lcll}
\hline Heteroskedasticity Test: Breusch-Pagan-Godfrey & & \\
\hline F-statistic & 1.283022 & Prob. F(4,3) & 0.4362 \\
Obs*R-squared & 5.048728 & Prob. Chi-Square(4) & 0.2823 \\
Scaled explained SS & 0.127613 & Prob. Chi-Square(4) & 0.9980 \\
\hline
\end{tabular}

Source: EViews 10 Output.

$\mathrm{H}_{0}$ : Homoskedasticity.

$\mathrm{H}_{1}$ : Heteroskedasicity.

The above result tests that the null hypothesis that the error variances are all equal versus the alternative that the error variances are a multiplicative function of one or more variables. The result show that it is free from Heteroskedasticity and the variance are equal (Homoskedasticity) with P-value 0.4362 which is greater than 0.05 at $95 \%$ confidence interval for rejecting null hypothesis.

Table 5. Test for multicollinearity.

\begin{tabular}{llll}
\hline Variance Inflation Factors & & & \\
\hline Sample: 1 10 & & & \\
\hline Included observations: 8 & & Uncentered & Centered \\
\hline \multirow{2}{*}{ Variable } & Coefficient & VIF & VIF \\
\cline { 2 - 4 } & Variance & 10451.89 & NA \\
DDLNCPS & 63.49848 & 1.472508 & 1.472430 \\
DLNFGB & 0.719220 & 1.653701 & 1.605086 \\
DLNTBR & 0.246071 & 1.300526 & 1.242845 \\
LNPNT & 0.022031 & 10431.72 & 1.392242 \\
\hline
\end{tabular}

Source: Eviews 10 Output.

Decision rule.

VIF $=1$ (Not correlated).

$1<$ VIF $<5$ (Moderately correlated).

VIF $>=5$ (Highly correlated). 
Table 6. Correlation Analysis.

\begin{tabular}{|c|c|c|c|c|c|}
\hline \multicolumn{6}{|c|}{ Covariance Analysis: Ordinary } \\
\hline \multirow{4}{*}{\multicolumn{6}{|c|}{$\begin{array}{l}\text { Sample: } 310 \\
\text { Included observations: } 8 \\
\text { Balanced sample (listwise missing value deletion) } \\
\text { Correlation }\end{array}$}} \\
\hline & & & & & \\
\hline & & & & & \\
\hline & & & & & \\
\hline \multirow{3}{*}{$\begin{array}{l}\text { Probability } \\
\text { DDLNCPS }\end{array}$} & DDLNCPS & DLNFGB & DLNTBR & LNBDI & LNPNT \\
\hline & 1.000000 & & & & \\
\hline & ----- & & & & \\
\hline \multirow[t]{2}{*}{ DLNFGB } & -0.351190 & 1.000000 & & & \\
\hline & 0.3937 & ----- & & & \\
\hline \multirow[t]{2}{*}{ DLNTBR } & 0.288947 & -0.414687 & 1.000000 & & \\
\hline & 0.4876 & 0.3070 & ----- & & \\
\hline \multirow[t]{2}{*}{ LNBDI } & -0.362660 & -0.136495 & -0.253724 & 1.000000 & \\
\hline & 0.3773 & 0.7472 & 0.5443 & ---- & \\
\hline \multirow[t]{2}{*}{ LNPNT } & -0.298209 & -0.306398 & 0.061476 & 0.559905 & 1.000000 \\
\hline & 0.4731 & 0.4604 & 0.8850 & 0.1490 & ---- \\
\hline
\end{tabular}

\subsubsection{Test for Multicollinearity}

Variance inflation factors (VIF) measure how much the variance of the estimated regression coefficients is inflated as compared to when the predictor variables are not linearly related. The results from the above table show that the variables are not suffering from multicollinearity (no correlation between predictors) since the VIF are less than 5 . Table 6 is the correlation matrix that show how the variables are associated with each other and there probabilities.

\subsection{Discussion of Results}

The result on Table 3 shows that the coefficient of determination, $R$ - Squared $\left(R^{2}\right)=0.434457$ (43.5\%), which means that $43.5 \%$ of the variation in the dependent variable (BDI) can be accounted for by the independent variables; CPS, FGB, TBR and PNT.

PNT have positive effect on BDI although not significant effect. The a priori expectation is that lending rate will rise when government borrowing rises. This support the assertion of [16].

CPS, FGB and TBR have negative effect on BDI though they are all not significant with probabilities greater than 0.05 at $95 \%$ confidence interval. The CPS, have negative effect on BDI though not significant implying that government borrowing may not have crowded-out private sector credit. This support the assertions of $([16,22,33]$. The FGB and TBR have negative effect on BDI though they are all not significant. This could imply that banks increase their investment in government securities (risk free securities) because of excess liquidity.

\section{Summary and Conclusion}

This study looked at the effect of government domestic borrowing on the private sector lending $\mathrm{n}$ Nigeria. The study employed the OLS multiple regression in analyzing the data sourced from 2009 to 2018 The results indicates that there is a negative relationship between government domestic and credit to private sector. However, this relationship is not statistically significant implying that government borrowing may not have crowded-out private sector credit. The results also show that prime lending rate has a positive effect on government bond issuance although not significant. These research results are important for understanding the mechanism through which government borrowing affects the private sector. This study finding suggests that government domestic borrowing in Nigeria may have resulted in the reduction of private credit and this works through the credit channel and the interest rate channel. These results have some policy implications. For policy makers they should note that substantial and persistent levels of government domestic debt can cause downward pressure on domestic loanable funds and hence hinder private investment. The importance of developing and maintaining strong institutions to control spending, manage debt cannot be overemphasized.

\section{References}

[1] Abbas, S. M., \& Christensen, J. E. (2007). The Role of Domestic Debt Markets in Economic Growth: An Empirical Investigation for Low-income Countries and Emerging Markets. Washington DC: International Monetary Fund.

[2] Abubakar Ado, A., Adegoke Ibrahim, A., \& Augustine, U. (2019). Government Borrowing Behaviour: Implications For Private Sector Growth In Nigeria. International Journal of Sustainable Development \& World Policy, 8 (2), 68-82. doi: 10.18488/journal.26.2019.82.68.82.

[3] Adegboye, A. A., \& Alimi, R. S. (2017). Public - Private Investment Nexus in Developing Economies: Does Financial Sector Development Matter for Nigeria? Munich: Munich Personal RePEc Archive.

[4] Aimola, A., \& Odhiambo, N. (2018). A Review of Public and Private Debt Dynamics in Nigeria. The Scientific Journal for Theory and Practice of Socio-economic Development, 14, 118. doi: 10.5281/zenodo.3600248.

[5] Akomolafe, K. J., Bosede, O., Emmanuel, O., \& Mark, A. (2015). Public Debt and Private Investment in Nigeria. American Journal of Economics, 5 (5), 501-507.

[6] Alesina, A., \&Perotti, R. (1996). Fiscal discipline and the budget process. The American Economic Review, 86 (2), 401407. 
[7] Al-Majali, A. A. (2018). Crowding Out Effect of Public Borrowing: The Case of Jordan. International Review of Management and Marketing, 8 (1), 119-125.

[8] Anyanwu, A., Gan, C., \& Hu, B. (2017). Government Domestic Debt, Private Sector Credit, and Crowding Out Effect in Oil-Dependent Countries. Journal of Economic Research, 22, 127-151.

[9] Asaleye, A. J., Oladipo, A. O., \& Obasaju, B. O. (2018). Domestic Debt Sustainability and Private Sector in Nigeria: Implications on Employment. The Journal of Social Sciences Research, 5, 842-848. doi: 10.32861/jssr.spi5.842.848.

[10] Atabaev, N., Ganiev, J., \& Alymkulova, N. (2018). Crowdingout (or -in) Effect in Transition Economies: Kyrgyzstan Case. International Journal of Development Issues, 17 (1), 102-113. doi:/10.1108/IJDI-09-2017-0144.

[11] DMO. (2020, March 5). www.dmo.gov.ng/debt-profile. Retrieved 2020, from www.dmo.gov.ng.

[12] Emran, M. S., \& Farazi, S. (2009). Lazy banks? Government borrowing and private credit in developing countries. Institute for International Economic Policy Working Paper, 9.

[13] Ewubare, D., Nteegah, A., \& Okpoi, G. (2017). Public Borrowing and the Nigerian Economy: An Autoregressive Distributed Lag Model (ARDL) approach. The International Journal of Social Sciences and Humanities Invention, 4 (5), 3506-3514. doi: 10.18535/ijsshi/v4i5.07.

[14] Funashima, Y., \& Ohtsuka, Y. (2017). Spatial Crowding-out and Crowding-in Effects of Government Spending on the Private Sector in Japan. Tohoku Gakuin University, Faculty of Economics. Tohoku Gakuin: Tohoku Gakuin University.

[15] Gbenga, O., James, S. O., \& Adeyinka, d. J. (2019). Determinant of Private Sector Credit and Its Implication on Economic Growth in Nigeria: 2000-2017. American Economic \& Social Review, 5 (1), 10-20.

[16] Hasnat, T., \& Ashraf, S. (2018). Is government borrowing crowding out long term debt resources: An empirical enquiry from India. International Journal of Emerging Markets, 13 (6), 1719-1731. doi:/10.1108/IJoEM-05-2017-0171.

[17] Huang, Y., Pagano, M., \& Panizza, U. (2019). Local Crowding Out in China. Goethe University Frankfurt. Frankfurt: The Center for Financial Studies.

[18] Idowu, Sanni, H. T., Akpan, D. B., Ekeocha, P. E., IkennaOnonugbo, A. A., Penzin, D. J.,... Opiah, D. C. (2018). Government Borrowing: Implications for Macroeconomic Stability and Growth in Nigeria. Economic and Financial Review, 56 (1), 55-97.

[19] Kharusi, S. A., \& Ada, M. S. (2018). External Debt and Economic Growth: The Case of Emerging Economy. Journal of Economic Integration, 1, 1141 1157. doi: 10.11130/jei.2018.33.1.1141.
[20] Lee, M.-w., \& Goh, K.-1. (2019). Bond Market Development in Malaysia: Possible Crowding-Out from Persistent Fiscal Deficits? Economics Bulletin, 39 (3), 1798-1807.

[21] Lidiema, C. (2018). Effects of Government Borrowing on Private Investments in Kenya. Journal of Finance and Economics, 6 (2), 49-59.

[22] Manda, S. (2019). Does Government Borrowing Crowd Out Private Sector Investment in Zimbabwe? Asian Journal of Economics, Business and Accounting, 12 (1), 1-9. doi: 10.9734/AJEBA/2019/v12i130142.

[23] Maric, Z. (2015). Crowding out vs crowding in effects in transitional countries. Perspectives of Innovations, Economics and Business, 15 (2), 136-146. doi: 10.15208/pieb.2015.13.

[24] Murungi, S. M., \& Okiro, K. (2018). Impact of Government Debt on Economic Growth in Kenya: A Critical Literature Review. European Scientific Journal, 14 (1). doi: 10.19044/esj.2018.v14n1p240.

[25] Nwaeze, N. C. (2017). Public Borrowing And Private Investment in Nigeria: Any Crowding Out Effect? Journal of Research In National Development, 24-34.

[26] Oke-Bello, A. M., \& Toriola, A. K. (2019). The Nexus between Fiscal Deficit and Domestic Credit in Nigeria (19812017). KIU Journal of Social Sciences, 5 (3), 35-46.

[27] Okon, E. O., \& Osinimu, O. J. (2017). Interest Rate and Private Sector Investment Relationship in Nigeria: CrowdingIn or Crowding-Out Effect (A Look at Small and Medium Enterprises. International Journal of Investment Management and Financial Innovations, 3 (2), 10-23.

[28] Omodero, C. O. (2019). Domestic Debt and Private Sector Credit in Nigeria: An Empirical Investigation. CECONOMICA, 15 (6), 188-207.

[29] Omojolaibi, J. A., Okenesi, T.-N. P., \& Mesagan, E. P. (2016). Fiscal policy and private investment in selected West African countries. CBN Journal of Applied Statistics, 7 (1), 277-309.

[30] Paul, N. (2017). Analysis of the Impact of External Debt on Economic Growth in an Emerging Economy: Evidence from Nigeria. African Research Review, 14 (4), 156-173. doi:/10.4314/afrrev.v11i4.13.

[31] Shanmugam, M. (2017). Does public investment crowd-out private investment in India. Journal of Financial Economic Policy, 9 (1), 50-69. doi:/10.1108/JFEP-02-2016-0016.

[32] Shetta, S., \& Kamaly, A. (2014). Does the Budget Deficit Crowd-Out Private Credit From the Banking Sector? The Case of Egypt. Topics in Middle Eastern and North African Economies, 2, 251-268.

[33] Zaheer, S., Khaliq, F., \& Rafiq, M. (2019). Does Government Borrowing Crowd out Private Sector Credit in Pakistan. Journal of Finance \& Economics Research, 4 (2), 30-42. doi: 10.20547/jfer1904203. 